The Canadian Journal of Higher Education La revue canadienne d'enseignement supérieur

Volume XXXV, No. 4, 2005 pages 85 - 110

\title{
Principles of Learner-centered Curriculum: Responding to the Call for Change in Higher Education
}

\author{
MARTHA CLEVELAND-INNES \\ Athabasca University \\ CLAUDIA EMES \\ University of Calgary
}

\begin{abstract}
Using well-known tenets of student development and student success as a central organizing premise, it is suggested that higher education curriculum should include outcomes related to the development of students as competent, lifelong learners. This imperative is driven by demands on higher education to prepare graduates for complex, dynamic, and information based social and occupational experiences. Curricula that prepare students with appropriate knowledge and skills to manoeuvre a changed and changing society is in order. Labelled a learner-centred curriculum, this approach includes, but goes beyond, the already explored learner-centred instruction (Lieberman, 1994; McCombs \& Whistler, 1997; SCCOE, 2000; Soifer, Young \& Irwin, 1989) to content and skill development regarding the mechanisms of learning and growth.
\end{abstract}

The Canadian Journal of Higher Education Volume XXXV, No. 4, 2005 


\section{RÉSUMÉ}

Utilisant des principes bien connus du développement et du succès de l'étudiant comme prémisse centrale d'organisation, la réforme du programme d'enseignement supérieur doit inclure des résultants liés au développement de l'étudiant en tant qu'apprenti compétent à vie. Cet impératif est motivé par la nouvelle exigence en matière d'enseignement supérieur pour préparer les diplômés à des expériences sociales et professionnelles complexes, dynamiques, et basées sur l'information. Un nouveau programme qui prépare les étudiants à des connaissances et compétences appropriées pour faire avancer une société qui change constamment. Perçue comme un programme axé sur l'élève, cette approche inclu et dépasse le cadre de l'enseignement personnalisé déjà étudié à fond (Lieberman, 1994; McCombs \& Whistler, 1997; SCCOE, 2000; Soifer, Young \& Irwin, 1989). Elle comprend le développement du contenu et des aptitudes relatif aux mécanismes d'apprentissage et de croissance.

\section{INTRODUCTION}

An updated structure for curriculum in higher education will provide greater opportunity for students to manage their own learning. This serves as the central proviso of a learner-centered curriculum; a set of learning experiences that allow students to meet curriculum requirements and participate fully in the arrangement of their own learning experiences, such that they learn to do so successfully and continue to do so when their formal education is complete. At the same time, this can allow faculty to maintain focus on content issues, ensuring what is learned is most current and relevant.

This new structure requires, among other things, new roles for faculty and students. "Role" is used here as a sociological construct, de ned as a collection of behavioural requirements associated with a certain social position in a group, organization or society (Kendall, Murray \& Linden, 2000). Creation of these new roles will develop as three other required changes occur. First, required outcomes for content mastery and skill

The Canadian Journal of Higher Education

Volume XXXV, No. 4, 2005 
development must be clear, explicit and readily available as a student makes his or her way through a program; expectations must be clear for appropriate behaviours to emerge. With this information, students participate actively in realizing outcomes. Second, what is known about human development and successful learning must become part of the curriculum. Rather than simply use all that is known about learning and development for students in higher education, curricula will be created that includes the requirement for things such as student involvement, student effort, faculty-student and student-student interaction, and deep rather than surface learning. In this way, development as a learner becomes an explicit part of the curriculum. Finally, a learner centered curriculum will offer a breadth of opportunities that demonstrate all possible mechanisms for learning, and offer "blended" choices of curriculum delivery to students in order to most readily realize required outcomes.

The key identi er of a learner centred curriculum is the inclusion of outcomes related to knowledge and skill about learning and human development. Students will learn, as part of a formal program, how to readily engage in creating personalized and effective strategies of learning. This common knowledge would cover topics like the types and outcomes of student involvement, student effort, approaches to learning and various types of social and academic interaction. The second key premise is the development of new roles for students and faculty. For faculty, this means expanding requirements in the role of instructor to include the teaching of learning related behaviours, as students develop expertise in a eld of study. Faculty will support increased responsibility for students, rewarding learning by increasing student control over the learning process (Garrison, 1992). For the students, required behaviours, attitudes and values as participants in higher education must translate into the roles of independent, continuous, active learners. These roles will emerge, as an outcome of higher education curriculum which includes knowledge and skill required to support lifelong learning. In other words, higher education will accept the responsibility of developing individuals able to design and manage their own learning and growth.

We can draw examples of a learner-centred curriculum from the work of Boomer, Lester, Onore and Cook (1992) within the K-12 system. These 
scholars discuss a negotiated curriculum that places the student at "the center of their own learning" (p. 139) by validating the knowledge they already possess and encouraging them to take responsibility for their own and their peers' learning. Many students come to higher education with this type of school-based learning experience. When they arrive in the lecture halls of post-secondary institutions, the most obvious role available is that of passive learner.

\section{The Call for Change}

We have heard a call for change in higher education throughout the past decades, asking for a response to "the needs of an information- and technology-based global economy, the complexities of modern life, the accelerated pace of change and the growing demands for competent, highskill performance in the workplace" (WGHE, 1993). This requires that "we produce much higher numbers of individuals whether high school, community college or four-year graduates prepared to learn their way through life" (emphasis added). This call is congruent with, but goes beyond, our passage from an information era to the knowledge era (Cogburn, 1998). Higher education is being asked to go beyond creating and disseminating knowledge, and assist in the process of interpreting emergent knowledge from a vast array of information sources that have invaded our lives. Western society is "demanding more exible, selfreliant workers and is making these demands on a [sic] schooling system" (Boomer, Lester, Onore and Cook, 1992, p. 283). Lest we over-emphasize education as a service only to society, we add that a learner-centred curriculum will empower learners to be in charge of their own learning, serving both the individual and the collective. This change must include both learner and professor, who now share "access to powerful learning systems, information and knowledge bases, scholarly exchange networks, or other mechanisms for delivery of learning" (Dolence \& Norris, 1995, p. 9).

To date, the response to this imperative to change has focused on two central themes: changing content and modularization. Change that focuses on content does not include skills for life-long learning and adaptability to a global economy. Modularization offers a solution for exible, distributed

The Canadian Journal of Higher Education

Volume XXXV, No. 4, 2005 
learning and adaptability for "just in time learning". However, it is not suf cient to require new content and new packaging of knowledge. Those prepared to learn their way through life need to understand, in a comprehensive way, the processes of learning and their individual roles as learners. Little, if any, evidence exists that higher education institutions actively embrace student engagement in the construction and design of programs or course curriculum. Current involvement tends to be based on limited course selection at the buffet table of core courses, humanities, science, social science and open options. Rather than learning about learning, this method of constructing curriculum usually leaves the student wondering why and how they ended up in some of the courses they take. There appears to be two levels of curriculum: that which is offered, and that which is taken. Participation in curriculum design, not merely course selection, must accompany a new student role of active involvement in the creation and delivery of curriculum.

Decreased public funding to higher education institutions, and increasing demands for accountability of university results or outcomes, has so far only led to tinkering at the margins instead of fundamental restructuring of the way we create and deliver undergraduate education at universities (Barr \& Tagg, 1995; Emes \& Cleveland-Innes, 2003). According to the Boyer Commission (1998), attempts to recast the undergraduate experience in North American universities has resulted in innovative changes to various aspects of undergraduate education but does not amount to signi cant restructuring as a whole. Attempts to shift to a learning paradigm, in which the needs and individual powers of the learner in relation to the curriculum material hold centre stage (as opposed to a curriculum paradigm in which the material to be covered, as expressed in the syllabus, is central and the learner does her or his best to master it by whatever means), have lead to little substantive change. According to the Boyer Commission (1998),

for the most part fundamental change has been shunned; universities have opted for cosmetic surgery, taking a nip here and a tuck there, when radical reconstruction is called for. Serious responses to complaints about undergraduate teaching have generated original and creative pedagogical and curricular experiments. But too often bold and promising efforts have vanished after external 
grant support disappeared, have withered on the fringes of the curriculum, or have been so compromised that their originality has been lost. (Radical Reconstruction section, 1)

We believe the singular most important response lies within a reconceptualization and implementation of a new curriculum template.

How does the implementation of a new curriculum template $t$ into the big picture of organizational change? In Peterson's (1997) notion of planning, constant reference to contextual information from many vantage points weave the complexities of changing social conditions into planning for higher education. Some factors seem distant from the curriculum; others have a critical impact. This can occur in our planning processes whether curricular change is part of the broader systemic change called for in higher education (Western Policy Exchange Project, 1999) or the central driver for change in institutions. External, contextual drivers for change include factors such as government funding and the need for increased accountability but, most importantly, rapid developments in technology are changing everything. Higher education no longer has a monopoly on knowledge distribution through learning opportunities. Advances in online learning have had an unprecedented impact on student involvement with the selection and packaging of learning materials. Blended learning that combines face-to-face instructional interaction with online learning is increasingly accepted as an alternative to exclusively classroom delivery. It is in this context that we suggest a new template for curriculum design. Curricular change is required to provide an adequate response to the most signi cant driver for change: the need to prepare learners for continuous, lifelong learning.

\section{Considering Curriculum}

The term curriculum, in general usage, means a program of study: a set of courses and their content and related activities of study. An ambiguous term, curriculum has de ed detailed description and de nition (Stark \& Lattuca, 1997). In a shared understanding of the term, we are likely to agree that it encompasses (1) a set of activities that someone in authority deems required to lead to some assumed or stated objectives, (2) the content, or syllabus, on which activities deemed to foster learning are focused, (3)

The Canadian Journal of Higher Education

Volume XXXV, No. 4, 2005 
projected outcomes or hoped for results, either implicit or explicit, and (4) a context which in uences, shapes and constrains the curriculum and its implementation.

Beyond possible agreement on these broader characteristics, various types of curriculum, identifying philosophical underpinnings in the teaching - learning transaction that shapes the curriculum, are available. Student inquiry learning methods (Hudspith \& Jenkins, 2001) and more recently constructivist curriculum methods (Gagnon \& Coolay, 2001) challenge the notion of "planning for teaching" in favour of "designing for learning". Consider the movement of curriculum integration from the late 1980s. This saw a move to apply knowledge to issues of personal and social relevance, with organizing structures around life as it is experienced by the students (Drake \& Burns, 2004). Some striking and successful experiments in 'designing for learning' curriculum have been made by McMaster Medical School and Harvard Medical School. These professional schools prepare their students, not by specifying all aspects of the syllabus to be covered and all skills to be developed, but by setting "problems" in large contexts in which the students, both individually and in small groups, work through such problems. In problem-based curriculum, students not only master the traditional syllabus and skills required but are arguably better equipped for the lifelong learning task which they will face as professionals. The possibility of a new role for students in their own learning has been amply demonstrated by such examples.

Aside from these remarkable exceptions, examples are not widespread. It is possible that concerns about the obligation to meet high standards on speci c academic requirements are holding back any curricular changes that give more decision-making and responsibility to students. Of note is the extent to which curriculum has been prepared in the hands of a few and then implemented for many, apparently homogeneous, individuals. Objectives and outcomes of curriculum are arranged separate from and outside of the voices of the learners, to suit requirements within a discipline or those of a speci $\mathrm{c}$ accreditation. This unidirectional approach to curriculum design and implementation is in question in institutions of higher education (Boyer Commission, 1998; Krysco \& Cleveland-Innes, 1999). In relation to content requirements, this is dif cult to dismiss. But 
in terms of decisions about learning practice and process, the learner must now be more engaged. The version oflearner-centered curriculum presented here, which can include inquiry based and problem based processes, opens up opportunities for students to more fully engage in shaping their learning experiences and constructing their own knowledge structures, within the boundaries of required content outcomes. The question of "who decides" on what aspects of curriculum design is a critical debate (Wilson, 1996).

Critical literature has evolved in the direction of student selfresponsibility and the central role of self in education. Baxter Magolda (2001) recommends that "transforming higher education to place self as central is necessary" (p. 4) in order to assist students meet expectations and be better prepared for life after college. Placing the student at the centre of the learning equation is not new (Dewey, 1938; Baxter Magolda, 1992) nor is the concept of preparing students for lifelong learning (Kolb, 1984). Chickering and Reisser (1993) proposed four curriculum axioms designed to assist students for the twenty- rst century: "make content relevant to students' backgrounds and prior experiences" (p. 363); "recognize signi cant dimensions of individual difference between students" (p. 364); "create encounters with diverse perspectives that challenge pre-existing information, assumptions, and values" (p. 365); "provide activities that help students integrate diverse perspectives, assumptions value orientations" (p. 367). Drake and Burns (2004) articulate the bene ts of integrated curriculum: integrating the lived worlds of learners, social integration, integration of knowledge and integration as a curriculum design. This body of work can guide and provide substance for new outcomes in a learner centred curriculum.

\section{Notions of Students in Receipt of Curriculum}

What are the implications of placing the learner as central to the learning equation? To recap: as the context of higher education changes, so the process and structure of higher education must change. Those things currently known to be critical in the teaching and learning process must be maintained, whatever outcomes are desired. This requires we take stock of what we know and is still relevant in the new context. A learner centred curriculum, as we de ne it, should therefore take into account the

The Canadian Journal of Higher Education

Volume XXXV, No. 4, 2005 
signi cant work already done regarding student development, learning environments and learning theory. In fact, not only should curriculum be informed by this, it should be included as part of the curriculum. In other words, a learner-centred curriculum will include the information known to those in authority about teaching and learning, so a student becomes more aware of, and more in control of, his or her own learning.

A thorough review of the vast literature on the student experience in higher education is not possible here. However, well-known theory regarding student success is outlined here to de ne what is critical for any higher education curriculum, and what must be included for students as part of a learner-centred curriculum. Given the extensive literature that implicitly or explicitly addresses issues associated with learnercenteredness, the case for new roles for faculty and students in relation to curriculum must rst address what is currently known about students in higher education.

To begin with, we know there are differences between males and females, and that as students mature, so to does learning. Perry's (1970) study of development explores the notion of how male students' thoughts and values develop in the transition from adolescence to adulthood. A developmental scheme of intellectual operations (positions) was produced that informed both curriculum design and teaching methods. It highlighted two major issues of student development: sequential forms of major personal development, and, the courage required of a student to make the decision for himself to take up the responsibilities of each new step. Belenky, Clinchy, Goldberger, and Tarule (1986) countered Perry's all male study by focussing on women and in so doing identi ed ve categories or ways of knowing that re ect women's perspectives. Whereas Kitchener and King (1981) need Perry's scheme to articulate relativistic processes, their model recognizes the increasing complexity, sophistication, and comprehensiveness of knowing through the identi cation of a seven stage sequence. Concurrently, the avenue of cognitive and learning styles was pursued. Its greatest contribution has been to highlight the diversity and complexity of cognitive processes and related behaviours (Kolb, 1984).

It is this cognitive process and related behaviours that ultimately lead to learning outcomes. It is also known that the learning environment is pivotal 
to learning outcomes. According to Entwistle (2000), faculty members are most likely to say poor performance on learning outcomes is a lack of ability or, or in the case of adequate competence, a lack of motivation on the part of the student. That is not what is meant by a student-centered approach to understanding teaching! In contrast, the notion of a studentto-environment $t$ permeates work on the relationship between students, his or her learning environment and outcomes. This concept took us out of the mindset that individual student characteristics are the central driver in student success. Tinto's (1975) model of student attrition and Weidman's (1989) model of student socialization provide support for the contribution of social environment to learning outcomes, as mediated by student-faculty and student-student interaction.

Related to this conceptually, Astin's theory of involvement (1977, 1985, 1993) suggests that student learning is a function of involvement in both the academic and social aspects of formal learning experiences. Supported by Freud's theory of cathexis, an involved student invests considerable energy in the formal and informal structures of campus life, as evidenced by spending time on campus, participating in student organizations and activities, and interacting with faculty. Through this investment, the activity "acts back" on the student, fostering individual change labelled as development.

For Astin $(1977,1985,1993)$, the role of student moves out of the role of passive receptor identi ed initially in an "input-process-output" model of education. In the theory of involvement, students engage in what the sociologist Goffman (1959) would call "role making" behaviour, by crafting his or her own level of involvement in the academic and social activities of campus. Level of involvement demonstrates a direct relationship to the amount of student learning and development, making student investment of time in campus life a critical factor in learning outcomes.

Much has been investigated and written about the role of motivation and successful learning. Motivation is the foundation of student involvement and invested time. Pace's (1979) work on student effort addresses this. For Pace, learning occurs at the intersection of mutual responsibility between students, faculty and the learning environment. The College Student Experience Questionnaire (CSEQ) rests on Pace's theory. In a landmark

The Canadian Journal of Higher Education

Volume XXXV, No. 4, 2005 
study, Davis and Murrell (1993) performed extensive data analysis using the CSEQ. Findings indicated that student effort is a critical factor in student gains. Sparking the motivation to get involved, within each student or at least those who do not have it naturally, currently rests in the hands of those who know of this relationship between student effort and student gains.

Motives also inform the theory on student approach to learning. Spearheaded by Marton and Saljo (1976), this taxonomy of approaches to learning emerged from a study of student learning intentions and processes. Further developed by ongoing research (see, for example, Biggs, 1987, 1998; Entwistle, 1988, 1991, 2000; Entwistle \& Ramsden, 1983; Ramsden, 1992), approaches to learning are classi ed as deep, surface or achieving. They refer to motives and strategies related to the content itself, the task at hand or the need to perform, respectively. Like the theories of Pace and Astin, approaches to learning are seen to emerge out of the interaction between the individual student and the learning environment in which they study - both motives and strategies may be affected by learning environment (Cleveland-Innes \& Emes, 2005).

Learning environments that include faculty-student and peer interaction are deemed to enhance learning outcomes (Pascarella \& Terenzini, 1991) and play a key role in the involvement described by Astin, the effort as identi ed by Pace, the incidence of attrition as reported by Tinto (Cleveland-Innes, 1994), and may be an in uence in deep approaches to learning (Triggwell, Prosser \& Waterhouse, 1999). This information, along with other theory noted above, should not only guide the delivery of a learner-centered curriculum but is included as knowledge and skill outcomes embedded in the curriculum requirements.

\section{Principles of a Learner-Centred Curriculum}

The term learner-centred is noted in the literature as far back as 1969 (Ullmer, 1969) and has been linked to Dewey's notions of learning through experience (Delaney, 1999; SCCOE 2000) and Roger's (1969) notion of student-centred learning. We suggest that applying learner-centredness to curriculum will allow students to participate more fully in the arrangement 
of their own learning experiences in such a way that two key goals are realized. First, curriculum objectives will require that students engage in learning about learning processes, strategies and methods, that is, "metalearning". This requires embedding, in the curriculum, content and exercises about learning. Second, students will participate in the shaping of curriculum, such that learning experiences will more adequately meet their needs as learners. This will provide them with the opportunity to learn about design and construction of purposeful learning activities, based on sound knowledge about the generation of learning outcomes, and in reference to themselves as learners. Individual education plans will emerge, except plans will be created by the student in consultation with the teacher, rather than by the teacher in consultation with the student.

Current discussions and applications of learner-centeredness are generally not focused as such on curriculum. Much information exists about learner-centered teaching practice (Lieberman, 1994; McCombs, \& Whistler 1997; SCCOE, 2000; Soifer, Young \& Irwin, 1989); yet, we do not have a clear picture of what constitutes a truly learner-centered curriculum for general undergraduate education, outside the handful of professional schools that take it seriously. More information is available about learnercentered teaching practice in post secondary institutions (Gunawardena, 1992; O’Banion, 1997; Reese, 1994; Reynolds \& Wener, 1994). We have few examples of a form of curriculum design that includes, but also goes beyond, learner-centered teaching practice.Addressing the needs and learning styles of individual students in learner-centered teaching practice is important to learning outcomes but offers little information on curriculum design.

With the exception of some professional schools, most references to learner centeredness in the literature fail to achieve, or even aim at, either of the two key objectives identi ed above. Our assessment of the literature generally identi es approaches to learner-centeredness that focus almost exclusively on practice and ways of teaching in the classroom, approaches which say little about the learner's voice, little about the role of the student (beyond passive responder to teacher driven activities). Within the academy a demand to hear the voice of learners echoes throughout the halls of learning, especially in the senates and boardrooms. Graff

The Canadian Journal of Higher Education

Volume XXXV, No. 4, 2005 
(1992) contends that the undergraduate student voice has been essentially ignored in the debate over curriculum reform. The debate centres on the " 'traditionalists' who feel that the move toward a more 'expanded' and 'inclusive' curriculum has lead to a decline in the stature and quality of universities, and 'progressives', who welcome such a move" (Nemec, 1997, p. 216).

The contribution of past work on 1) curriculum characteristics and 2) learner development provide background for content and skills development in a learner-centred curriculum. Our de nition adds a critical, central organizing premise. What is known about and provided for students (for example, opportunities for engagement, activities that provide development, interaction for enhanced outcomes and learning environments that foster deep learning) will now become explicit and required content for the students themselves.

In this version of curriculum, the term learner refers to the role that is played (1) by the constituency of students in a program, that is, learners as a collective group, and (2) by each individual with unique attributes as they play this role of learner. A learner-centred curriculum addresses both. By the term "centred" we mean that the learner will be a continuous point of reference (but not the only point of reference) in curriculum decisions. In a learner-centred curriculum, students will be afforded opportunities for making informed curriculum decisions. Learner-centred programs facilitate learning about curricular decision-making processes, infused in both program decisions and course relevant decisions. Learners play an active, participatory, knowledgeable role and participation includes knowledge development in the area of learning and curriculum design. In a learner-centred curriculum, the faculty role will be adjusted to accommodate a new role for students.

The following principles guide the focus of a learner-centred curriculum:

\section{Explicit and Accessible Documentation of Required Outcomes for Content Mastery and Skills Development.}

An explicit program syllabus, which sets out in advance the knowledge and skills to be acquired in a program of study, is a central artifact of learner-centered curriculum. Explicit descriptions of courses, activities, 
assessment protocol and graduation requirements offer students a view of a program in its entirety. It speci es purposes and objectives of programs, how these may be achieved and tested, and what is expected by way of capabilities upon graduation. An explicit syllabus should optimize a variety of ways faculty members can teach and students can learn. For example, in reference to Principle 4 below, students are told in the syllabus the extent to which they will participate in online discussions to foster interaction and faculty will outline what role they will play in facilitating such discussions. The syllabus will be available to students in a web format and student affairs of ces before studies begin. This provides students the opportunity to read in detail, beyond course descriptions, what the experience of being in such courses will be like. It will also assist in choosing a program, and a constellation of courses, appropriate to individual interests, career aspirations and learning choices. Lastly, it will serve as a guide to the program as the student progresses through it.

During this progression, students will have more awareness of the purpose of instruction, and will be better prepared and better motivated to participate in educational experiences. Instructors will also have a clearer idea of how the content and skill development in any individual course ts into a student's whole program. The syllabus serves as a useful reference, a multipurpose guide to program design, content, and an invaluable tool for learning choices and assessment.

2. Explicit and Continuous Reference to Documented Evidence of Beneficial Student Experiences, Personal Development, and Learning Processes.

Currently, knowledge about student development and learning processes are held by student services personnel and some faculty. Some aspects of important in uences in student life and student success are presented in new student orientation and counselling workshops; part of so-called extra-curricular activities. A learner-centered curriculum will make two adjustments to this situation. First, what is known about student development, particularly as it relates to learning processes and learning outcomes, will form part of all curriculum, throughout activities of individual courses. Rather than being designed with content objectives in mind, and learning considerations being loosely applied

The Canadian Journal of Higher Education

Volume XXXV, No. 4, 2005 
during delivery, student development and learning processes will be explicit in the presentation of content, in the progression of material, and in assessment strategies. Early in their program students will be offered the opportunity to identify their own learning style through exercises that identify past individual learning successes or alternatively through standardized learning style assessment tools. Second, the knowledge and skills known to impact student approaches to successful learning will be part of the formal curriculum. As their program progresses students will then be introduced to the concept of deep and surface learning theory. Deep and surface learning theory identi es motivational patterns and resulting learning strategies that they can employ to realize either deep or surface learning. This may be done in small doses throughout courses in a program, or as an explicit, credit-based addition to programs. Curricular outcomes will thus include knowledge and skills related to learning.

\section{Choices will be Available Regarding Pathways to Master Skills and Knowledge, with Reference to Decision-making, Regarding AppropriateLlearning Opportunities.}

Critical to the structure and process of a learner-centered curriculum is the notion of "choice" regarding learning. A menu driven approach can facilitate this. At the course level this may translate into choosing from different forms of assessment and/or a variety of learning activities. For example, in a re ective exercise that requires interpretation of written material, students may be given the choice to participate in an online group discussion or to submit a re ective journal entry that represents a personal interpretation. Ramsden's (1992) work on teaching in higher education introduces the notion of freedom in learning; teaching provides optional pathways to master material. According to Schuell (1986)

if students are to learn desired outcomes in a reasonably effective manner, then the teacher's fundamental task is to get students to engage in learning activities that are likely to result in their achieving those outcomes... It is helpful to remember that what the student does is actually more important in determining what is learned than what the teacher does. (p. 429)

Schuell is referencing pathways at the course level; going a step further we suggest that curricula also provide the optional pathways that will 
engage learners in activities that provide choice not only of subject matter but also of delivery methods. Because it is not possible in higher education to provide individual education plans for each student, we suggest post secondary institutions expand curriculum choices, and the student create their own individual plan. Making the correct decisions regarding learning requires that the student understand the expected outcomes (principle one above) and themselves as a learner (principle two). If the explicit outcomes are realized the choice of delivery methods should be secondary. For example if a minor in aging requires a speci ed number of courses related to healthy aging, the student should be able to select those courses from a variety of sources including external institutions that deliver online learning.

4. Curriculum Delivery will be Flexible and Offer Choices that Result in Blended Learning.

To say a curriculum is exible is to bolster the enabling aspects of curriculum while crafting carefully those things that constrain. Currently curriculum exibility is available, given program requirements, in terms of choosing a pattern of courses, a speci c section of a course given at the certain time and delivered by a particular instructor. Delivery formats are relatively uniform however, involving instructor presentation and a variety of student assessment activities. In a learner-centered curriculum choice is expanded in two ways: arenas of choice will shift and menus lengthened through blended learning opportunities.

Although still a new approach to curriculum delivery, the concept of blended learning, which is a combination of face-to-face and online learning, provides an opportunity for a wider range of learning activities. In light of the growing popularity of blended learning, a learner centered curriculum will afford choice among the options of face-to-face, online, or blended learning. The balance of delivery methods in blended learning may vary not only from course to course but from learner to learner. For example one student in a psychology class may negotiate credit for six out of 10 units delivered online whereas a classmate may choose only four online units.

The Canadian Journal of Higher Education

Volume XXXV, No. 4, 2005 


\section{Clarity of Role Expectations and Required Behaviours as Life- Long Learners.}

This principle of a learner-centred curriculum assumes a different role for the student. It goes well beyond the role students become accustomed to in $\mathrm{K}-12$, that of either passive receptor or even of active receptor of knowledge wherein they have no hand in deciding how to master. Although the average age of university students has risen in the past 30 years, current planning and delivery of curriculum relates more to recent high school graduates. Our conceptualization of a new role for students is one that fosters and supports a more active engagement in program design, content, and delivery. For example in addition to learning outcomes that have been de ned in the explicit syllabus, students will be required to add several content-based learning outcomes of their own choosing. The design will be determined by the learning activities that they choose in order to achieve these outcomes. Further, they will identify and rationalize their choice of delivery methods.

Thus a learner-centred curriculum includes the learning activities required to prepare students in new roles as continuous learners. Once students leave the formal education environment, the requirement to learn will continue without the infrastructure provided while in school. Behaviours required after graduation will now be part of the curriculum. These new curriculum requirements create a new role for the student in higher education, one that continues to emerge and develop once the student graduates.

6. Role Adjustment for Faculty - Ensuring a Well-developed Position Exists as Content Expert in Combination with Support for Learner Development as a Deep, Independent and Selfmanaged Learner.

It is exciting yet dif cult to imagine a changing role for faculty, as currently this is so highly variable across institutions, disciplines, and faculty members, and suggesting role adjustment leaves out those already there. In addition to well-developed content expertise, already established as part of the role of faculty member, faculty must be well versed in the tenets of supporting learning. For example, faculty will understand variations in learning style. They will include in their course design strategies that 
foster deep rather than surface learning. In the presence of well designed curriculum, with optimal choices for students, faculty will become expert at tting the content into curriculum requirements, rather than trying to $t$ teaching principles around a well known content.

In addition, faculty will support increased responsibility for students, rewarding learning by increasing student control over the learning process (Garrison, 1992). As students manoeuvre explicit learning objectives (Principle 1), in ways most appropriate to best known learning preferences and requirements (Principle 2) by making choices that will carry them anytime they are playing out the role of learner (Principle 3 ). The faculty role will shift to include guide and preceptor of the learning process.

\section{DISCUSSION}

The human actors in curriculum design and delivery carry out necessary activities within the requirements of the role assigned to them. Faculty and student roles in the learning enterprise currently re ect a long history of the professor in the dominant position of knowledge deliverer and the student as the receptive learner. Despite a determined measure of ambiguity around the respective roles and responsibilities, a sense of well-established activities for each can be observed in traditional university culture.

From her or his individual perspective as either a student or faculty member, each views current role requirements and expectations differently. Students view their roles as learner and that of the professor as teacher differently than professors view of the role of the learner and their own role as teachers. If this premise is correct, role ambiguity exists systemically in higher education. Changing demands on the programs and outcomes in higher education have exacerbated this role ambiguity. As part of the transition to a learner-centered curriculum we propose that revised roles for faculty and students will be agreed-upon and explicit, embedding role clarity into a new curriculum structure.

Role refers to the actions and behaviour expected of persons engaged in identi able social positions (Macionis, \& Gerber, 1999). Social role theory (Collier, 2001; Heiss, 1981; Layder, 1981; Lopata, 1995; Raffel, 1999; Smith, \& Kolosick 1996) provides a picture of the importance of

The Canadian Journal of Higher Education

Volume XXXV, No. 4, 2005 
clarity in role de nition for the smooth running of social engagement and the production of desired behavioural results. Current expectations in the role of both student and faculty are outdated given the new requirement of lifelong learning on the part of both students and their professors. In the case of the faculty-student role relationship, we must especially take note of the "self-other" character exhibited by social roles. In other words, the role each plays in a given setting is done in keeping with the expectations others generally hold for persons in that role.

This complementarity of roles is one key to unpacking what goes on between students and faculty; as expectations for one change, so too must the expectations for the other. Roles are identi ed in the social structure and are adopted through a process of socialization. Generally one acts within a role according to one's understanding of the required obligations and socially sanctioned privileges that are expected. Thus, in the context of a changing expectation for both faculty and learners in the universities of our time, moving learning experiences from the current subject-based, teacher directed curriculum to a learner-centered curriculum will require adjustments in the duties, obligations and privileges of roles.

Using role theory to conceptualize current curriculum, and changes to curricular structure and process, requires that we identify the place of human actors in curriculum design and delivery. As a conceptual frame of understanding, curriculum can be seen as the product of four commonplaces in education: the teacher, student, subject matter and milieu (Schwab, 1978). Out of respect for this work, we use Schwab's term "teacher" to identify the teaching portion of the role of faculty currently.

Schwab's model gives us the opportunity to consider the dynamic among these commonplaces, and to consider what this dynamic might look like as the central focus shifts. Moving away from the notion of curriculum that is subject-centred, our conception of learner-centred curriculum emerges out of the dynamic that exists in the multiple relationships among the commonplaces of curriculum where the role of learner acts as the point of departure for understanding all other relationships within the model.

Reviewing the dynamic aspects of Schwab's model requires the explication of the multiple separate relationships, and their interaction. The learner operates in a particular multi-faceted milieu, both on and 
off campus, in the present. Learning in higher education, however, has an embedded "for the future" tense to it; learners participate in higher education in preparation for future roles and activities in a broader milieu or environment. In higher education, learners operate from within the role of "student", identi able by the formalized, legitimized set of privileges and expectations. One is not in the role of student without an identi cation card, which is gained only after a successful admission process and the payment of fees. In this legitimate role, the student acts on, and is acted upon by, the teacher, the subject matter and the milieu. The balance between the extent to which students act on the other commonplaces in curriculum and the extent to which they are acted on is at the heart of our theory. Learner-centred curriculum embodies the notion that students, in this legitimate role, be granted more opportunity to act in concert with their environment, the teachers and the subject matter. For learner-centred curriculum, development begins focused on the 'commonplace' learner, but not as an isolated 'place.' The learner who will be both enabled and constrained by the curriculum must be seen as a dynamic actor who will be encouraged to, and supported in, their own version of dealing with the enabling and constraining aspects of the curriculum.

\section{CONCLUSION}

This article approaches the concept of a learner-centered curriculum from several key perspectives. First, successful implementation will begin with a shift in the roles of student and professor. Second, students and academics will be equally conversant on how and why curriculum choices are made. For the student this will lead to better understanding of designing a learning process and the integration of meta-learning as part of the curriculum.

Lastly, curriculum design will re ect greater student driven choice as ubiquitous technology provides opportunities for blended learning that soon will be pervasive throughout the curriculum.

We contend that current curriculum structures places students in a subordinate role and that the shift from subordinate to the role of a participant in a shared journey of learning is the benchmark of learner-

The Canadian Journal of Higher Education

Volume XXXV, No. 4, 2005 
centeredness. The student will be part of the co-creation of the learning experience. Evidence of learner-centred curriculum is found in the extent to which students are free to participate. Faculty will continue to set boundaries, but students will be supported individually to greater participation in curriculum design through opportunities to express themselves while ful lling their shared responsibility in the design and delivery of curriculum. For example, faculty set boundaries around the sequence in which courses will be delivered, the knowledge outcomes, and the standards of assessment. Students, however, will have greater latitude in the choice of evaluation procedure, how the content is acquired and from where, and deadlines for ful lling requirements. In order to make these decisions, the learner needs detailed information, delivered in a timely fashion about the program and its courses. Therefore, an explicit program syllabus is required that provides in advance all the detail about a program; not just the content with goals and objectives, but the questions to be answered, the exercises, the assignments. These are all laid out in advance but incorporate choices for the student.

While the term learner-centered is often interpreted to mean that the learner drives the content, our de nition of a learner-centered curriculum leaves the experts in charge of the content. Learner-centred curriculum creates the appropriate environment for the role of learner to fully ourish and develop. The needs of the learner, required for maximum learning in this context for speci ed content and skill development, are centrally addressed. 
106 M. Cleveland-Innes \& C. Emes

\section{NOTES}

\section{Correspondence information}

Martha Cleveland-Innes

Associate Professor

Centre for Distance Education

Athabasca University

1 University Drive

Athabasca, AB T9S 3A3

(780) 675-6426

martic@athabascau.ca

Claudia Emes

Professor

Faculty of Kinesiology

University of Calgary

2500 University Drive NW

Calgary, Alberta T2N 1N4

(403) 220-7019

cemes@ucalgary.ca

The Canadian Journal of Higher Education

Volume XXXV, No. 4, 2005 


\section{REFERENCES}

Astin, A.W. (1993). What matters in college? San Francisco: Jossey-Bass.

Astin, A.W. (1985). Achieving educational excellence. San Francisco: JosseyBass.

Astin, A.W. (1977). Four critical years: Effects of college on beliefs, attitudes, and knowledge. San Francisco: Jossey-Bass.

Barr, B. \& Tagg, J. (1995). From teaching to learning: A new paradigm for undergraduate education. Change, 27(6), 12-25.

Baxter Magolda, M. B. (1992). Knowing and reasoning in college: Gender-related patterns in students 'intellectual development. San Francisco: Jossey-Bass.

Baxter Magolda, M. B. (2001). Making their own way. Toronto: Stylus publishing.

Belenky, M. F., Clinchy, B. M., Goldberger, N. R., \& Tarule, J. M. (1986). Women's ways of knowing: The development of self, voice and mind. New York: Basic Books.

Biggs, J. B. (1998). What the student does: Teaching for enhanced learning in the '90s. Higher Education Research and Development Society of Australasia Newsletter. Auckland, New Zealand. Retrieved August 3, 2003 from: http:// www2.auckland.ac.nz/cpd/HERDSA/HTML/TchLearn/BIGGS1.HTM

Biggs, J. B. (1987). Student approaches to learning and studying. Hawthorn, Victoria: Australian Council for Educational Research.

Boomer, G., Lester, N., Onore, C., \& Cook, J.. (1992). Negotiating the curriculum: Educating for the $21^{\text {st }}$ century. Washington, DC: The Falmer Press.

Boyer Commission. (1998). Reinventing undergraduate education: A blueprint for America's research universities. Retrieved January 31, 2002 from: http:// naples.cc.sunysb.edu/Pres/boyer.nsf/

Chickering, A. W. \& Reisser, L. (1993). Education and identity (2 ${ }^{\text {nd }}$ ed.). San Francisco: Jossey-Bass.

Cleveland-Innes, M. (1994). Adult student dropout at post secondary institutions. Review of Higher Education, 17(4), 423-445.

Cleveland-Innes, M. \& Emes, C. (2005). An empirical study of social and academic interaction in higher education and the effect on deep and surface learning. National Association of Student Personnel Administrators Journal. 42(2) http://publications.naspa.org/naspajournal/vol42/iss2/art7/

Cogburn, D. L. (1998). Globalization, knowledge, education and training in the information age. Retrieved January 22, 2002 from: http://www.unesco.org/ webworld/infoethics_2/eng/papers/paper_23.htm

Collier, P. J. (2000). The effects of completing a capstone course on student identity. Sociology of Education, 73 (October), 285-299.

Collier, P. J. (2001). A differentiated model of role identity acquisition. Symbolic Interactionist, 24(2), 217-235.

The Canadian Journal of Higher Education Volume XXXV, No. 4, 2005 
Davis, T. M. \& Murrell, P. H. (1993). Turning teaching into learning: The role of student responsibility in the collegiate experience. ASHE-ERIC Higher Education Report, no. 8. Washington, DC: George Washington University.

Drake, S. \& Burns, R. (2004). Meeting standards through integrated curriculum. Deisel Ebooks.

Delaney, J. G. (1999). What are learner-centered schools? Atlantic Provinces Education Foundation Summer Leadership Institute. Retrieved August 1, 2001 from http://www.stemnet.nf.ca/ape nstit99/article.html.

Dewey, J. (1938). Experience and education. New York: Macmillan Publishing.

Dolence, M. \& Norris, D. (1995). Transforming higher education: A vision for learning in the 21st century. Ann Arbor, Michigan: Society for College and University Planning.

Emes, C. \& Cleveland-Innes, M. (2003). A journey toward learner-centered curriculum. Canadian Journal of Higher Education, 33(3), 47-70.

Entwistle, N.J. (1988). Motivational factors in students' approaches to learning. In R.R. Schmeck, (Ed.), Learning strategies and learning styles (pp. 21-51). New York: Plenum Press.

Entwistle, N. J. (1991). Approaches to learning and perceptions of the learning environment. Higher Education, 22, 201-204.

Entwistle, N. J. (2000). Approaches to studying and levels of understanding: The in uences of teaching and assessment. In J. C. Smart (Ed.), Higher education: Handbook of theory and research, (pp. 156-218). New York: Agathon Press.

Entwistle, N. J. \& Ramsden, P. (1983). Understanding student learning. New York: Nichols Publishing.

Gagnon, G. W. \& Collay, M. (2001). Designing for learning: Six elements in constructivist classrooms. Thousand Oaks, CA: Corwin Press.

Garrison, D. R. (1992). Critical thinking and self-directed learning in adult education: An analysis of responsibility and control issues. Adult Education Quarterly, 42(3), 136-148.

Goffman, E. (1959). The presentation of self in everyday life. New York: Doubleday.

Graff, G. (1992). Beyond the culture wars: How teaching the con icts can revitalize American education. New York: W.W. Norton.

Gunawardena, C. (1992). Changing faculty-roles for audiographics and online teaching. American Journal of Distance Education, 6, 58-71.

Heiss, J. (1981). The social psychology of interaction. New Jersey: PrenticeHall.

Hudspith, B. \& Jenkins, H. (2001). Teaching the art of inquiry. Halifax, Nova Scotia: Society for Teaching and Learning in Higher Education.

Kendall, D., Murray, J., \& Linden, R. (2000). Sociology in our times. (2nd ed.). Ontario: Canadian Cataloguing in Publication.

The Canadian Journal of Higher Education

Volume XXXV, No. 4, 2005 
Kitchener, K., \& King, P. (1981). Re ective judgments: Conceptions of justi cations and their relationships to age and education. Journal of Applied Developmental Psychology, 10, 73-95.

Kolb, D. A. (1984). Experiential learning. Englewood Cliffs, NJ.: Prentice Hall.

Krysko R. \& Cleveland-Innes, M. (1999) Capturing the student voice: Undergraduate curriculum redesign from the student's point of view. Calgary, Alberta: The University of Calgary, The Learning Commons.

Layder, D. (1981). Structure, interaction and social theory. Boston: Routledge \& Kegan Paul Limited.

Lieberman, A. (1994). A culture in the making: Leadership in learner-centered schools. In J. Oakes \& K. Hunter Quartz (Eds.), Creating New Educational Communities: Schools and Classrooms Where All Children Can Be Smart. Chicago: University of Chicago Press. 108-129.

Lopata, H. Z (1995). Role theory. In J. R. Blau, \& N. Goodman, (Eds.) Social roles \& social institutions. New Brunswick, N.J.: Transaction Publishers.

Macionis, J. J. \& Gerber, L. M. (1999). Sociology. ( $3^{\text {rd }}$ Canadian ed.). Scarborough, Ontario: Prentice-Hall.

Marton, F. \& Saljo, R. (1976). On qualitative differences in learning: I-Outcome and process. British Journal of Educational Psychology, 46, 4-11.

McCombs, B. L. \& Whistler, J. S. (1997). The learner-centered classroom and school: Strategies for increasing student motivation and achievement. JosseyBass Education Series. San Francisco: Jossey-Bass.

Nemec, M. R. (1997). The role of curricular debate in the university. The Review of Higher Education, 20(2), 215-227.

O'Banion, T. (1997). Creating more learning centered community colleges. Newport Beach, CA.: League for Innovation in Community Colleges.

Pace, C. R. (1979). Measuring the outcomes of college. San Francisco: JosseyBass.

Pascarella, E. \& Terenzini, P. (1991). How college effects students. San Francisco: Jossey-Bass.

Perry, W. G., Jr. (1970). Intellectual and ethical development in the college years: A scheme. New York: Holt, Rinehart, and Winston.

Peterson, M. W. (1997). Using contextual planning to transform institutions. In M. W. Peterson, D. D. Dill, L.A. Mets, \& Associates (Eds.), Planning and management for a changing environment. San Francisco: Jossey-Bass. 127157.

Raffel, S. (1999). Revisiting role theory: Rules and the problem of the self. Sociological Research Online, 4(2). Ramsden P. (1992). Learning to teach in higher education. London: Kogan Page. Online journal http://www. socresonline.org.uk/socresonline/4/2/raffel.html. 
Reese, T. (1994, November). Adult learning research and effective college teaching: Perceptions and practice. Paper presented at the Association for the Study of Higher Education meeting, Tucson, Arizona.

Reynolds, J. \& Wener, S. C. (1994). An alternative paradigm for college reading and study skills courses. Journal of Reading, 37(4), 272-278.

Rogers, C. R. (1969). Freedom to learn. Columbus, OH: Charles E. Merrill Publishing Company.

SCCOE Internet Institute (2000). What is learner-centered instruction? Retrieved August 10, 2001 from http://etc.sccoe.org/i2000/00mod/b_projects/learner. html

Shuell, T. J. (1986). Cognitive conceptions of learning. Review of Educational Research, 56, 411-436.

Schwab, J, (1978). The teaching of science: The teaching of science as enquiry. Cambridge, MA: Harvard University Press.

Smith, K. \& Kolosick, T. (1996). The shift to a learner-centered university: New roles for faculty, students and technology. Retrieved January 15, 2002 from http://www.saintmarys.edu/ psmith/ksmith96.html.

Soifer, R., Young, D. \& Irwin M. (1989). The academy: A learner-centered workplace literacy program. New Directions in Continuing Education, 42, 6568.

Stark, J. S. \& Lattuca, L. R. (1997). Shaping the college curriculum: Academic plans in action. Toronto: Allyn and Bacon.

Tinto, V. (1975). Dropout from higher education: A theoretical synthesis of recent research. Review of Educational Research, 45, 89-127.

Trigwell, K., Prosser, M. \& Waterhouse, F. (1999). Relations between teachers' approaches to teaching and students' approaches to learning. Higher Education, $37,57-70$.

Ullmer, E. J. (1969). Instructional development in higher education: Basic premises of a learner centered approach. Education Technology, 9(4) 10-16.

Weidman, J. C. (1989). Undergraduate socialization: A conceptual approach. In J.C. Smart (Ed.), Higher education: Handbook of theory and research, Vol. 5. (pp. 289-322). New York: Agathon Press.

Western Policy Exchange Program (1993). [In the text it's cited as 1999] Policy in transition: Working toward systemic change in higher education in the west. Retrieved on January 31, 2002 from http://www.wiche.edu/WPE/Kellogg/

Wilson, B., (Ed.). (1996). Constructivist learning environments: Case studies in instructional design. New Jersey: Educational Technology Publications. [Needs city]

Wingspread Group on Higher Education (WGHE). (1993). An American imperative: Higher expectations for higher education. Retrieved August 14, 2001 from http://www.pbs.org/als/revolution/whatis/wingspread.htm

The Canadian Journal of Higher Education

Volume XXXV, No. 4, 2005 